\title{
STANDARD SETTING FOR THE EXTRACTIVE INDUSTRIES: A CRITICAL EXAMINATION
}

\author{
Dr Corinne Cortese \\ School of Accounting and Finance \\ University of Wollongong \\ NSW 2522 Australia \\ Telephone: +61242213697 \\ Facsimile: +61242214297 \\ Email: corinne@uow.edu.au \\ (corresponding author) \\ Dr Helen Irvine \\ School of Accounting and Finance \\ University of Wollongong \\ NSW 2522 Australia \\ Telephone: +61242215919 \\ Facsimile: +61 242214297 \\ Email: hirvine@uow.edu.au \\ Associate Professor Mary Kaidonis \\ School of Accounting and Finance \\ University of Wollongong \\ NSW 2522 Australia \\ Telephone: +61242213681 \\ Facsimile: +61 242214297 \\ Email:maryk@uow.edu.au
}

\begin{abstract}
This study examines the players involved in the setting of an international accounting standard for the extractive industries. Publicly available data is used to expose connections between key constituents involved in the process, to enhance understanding of how the international accounting standard setting process occurred, and to identify future research possibilities.
\end{abstract}

Key words: extractive industries; international accounting standards; standard setting.

INTRODUCTION

With the adoption of International Financial Reporting Standards (IFRS), a profound change has occurred in the way many entities, including the world's largest public companies, produce their general purpose financial reports. This is particularly significant in the case of extractive industries, with the International Accounting Standards Board (IASB) yet to develop a comprehensive international accounting standard. The IASB is still struggling to achieve consensus among the many and varied interests of constituents. With accounting and accounting standard setting now accepted as being highly politicised activities, this paper provides insight into the constituents who contribute to the development of an international accounting standard for the extractive industries. 
Defined as the petroleum (oil and gas) and mining industries (International Accounting Standards Committee, 2000a), the extractive industries have substantial economic, social, political, and environmental impacts. Many of the world's largest extractive companies, such as the Royal Dutch/Shell group, BP, BHP Billiton, and ExxonMobil, are well known and established household names. The economic strength of the major extractive industries companies is such that many are richer and more powerful than the states and even countries that seek to regulate them (Global Policy Forum, 2006). Indeed, six of the world's top twelve companies are from the extractive industries, being BP, Chevron/Texaco, ConocoPhillips, ExxonMobil, the Royal Dutch/Shell group, and TOTAL (Anderson and Cavanagh, 2000, Fortune Magazine, 2005). In 2005, these six companies recorded combined revenues in excess of US\$1.2 trillion and profits of US\$92 billion (Fortune Magazine, 2005). Comparing the combined revenues of these six global companies with current United States Gross Domestic Product of US\$11 trillion (World Bank, 2005) gives some perspective of the enormous economic strength of the major international extractive industries companies. The political influence of this sector flows on from its economic strength. Extractive industry coalitions have been active lobbyists in regulatory debates concerning issues such as global climate change, taxation policy, and sustainable development, with many, such as the American Petroleum Institute, formed specifically for the purpose of influencing public policy and regulatory processes for the benefit of members (American Petroleum Institute, 2006). The environmental impacts are arguably the most visible consequence of extractive activities, and the social impacts are also significant, with major extractive operations often responsible for improving infrastructure in and around the area being mined, increasing capital investment to a community and/or country, providing employment opportunities, and boosting local economies.

These substantial impacts contribute to the accountability of the extractive industries sector and make the formulation of financial reporting practices used by extractive industries companies a highly politicised activity. One aspect of extractive industries accounting that has been plagued by controversy concerns the method of accounting for preproduction activities. In an attempt to report on this phase of extractive operations in the most favourable light, the full cost and successful efforts methods of accounting have developed. ${ }^{1}$ These two methods of accounting have been the cause of considerable controversy within the extractive industries due to the significantly different results generated under each method. Companies in the US, Canada, and the United Kingdom are able to choose between these two methods of accounting when reporting on exploration and evaluation activities.

In 1998, the International Accounting Standards Committee (IASC) attempted to remedy these disparate accounting practices by proposing the development of an international accounting standard that enhanced comparability and consistency of financial reporting by extractive industries companies across the world (International Accounting Standards Committee, 2000a). This was to be achieved, in part, by narrowing accounting alternatives and prescribing a single method of accounting for exploration and evaluation consistent with the successful efforts concept (International Accounting Standards Committee, 2000a).

The full cost versus successful efforts issue was considered in the IASC's Extractive Industries Issues Paper (hereafter referred to as the Issues Paper), published in November 2000 (International Accounting Standards Committee, 2000a). The Issues Paper

\footnotetext{
${ }^{1}$ The area-of-interest method and appropriation methods are other derivatives of these two main methods, and are practised in Australia and South Africa respectively.
} 
was the first stage in the process of developing an international accounting standard for the extractive industries and, as part of the process, was opened for public comment until June 2001. Comment letters were received from 52 respondents, with many of these from multinational extractive industries companies and extractive industries lobby groups. While the majority of respondents supported the proposal to narrow accounting alternatives and require all companies to report under the successful efforts method, two industry lobby groups vehemently opposed the proposal and argued that both the successful efforts and full cost methods should continue to be permitted.

After a series of delays, partly due to the IASC's restructure and reformation as the IASB, an international accounting standard for the extractive industries was finally issued in December 2004 (International Accounting Standards Board, 2004b). However, despite the claimed intention of narrowing accounting alternatives and bringing about consistency in extractive industries reporting, in the resultant accounting standard, the IASB failed to achieve these objectives. Instead, International Financial Reporting Standard 6, Exploration for and Evaluation of Minerals Resources (IFRS 6), granted extractive industries companies an exemption from the restrictive provisions contained in other international accounting standards. This had the effect of enabling extractive industries companies to continue to use the accounting policies in place immediately before the adoption of IFRS 6 to account for exploration and evaluation expenditure. IFRS 6 merely codified existing industry practice, perpetuating the disparate methods of accounting for exploration and evaluation, and maintaining the status quo for extractive industries companies.

The striking failure of the IASB to follow through with its aim of remedying the inconsistencies of extractive industries accounting, particularly with respect to the successful efforts versus full cost issue led to a consideration of the possible factors that may have influenced this decision. Of interest, therefore, is the story behind the process of setting the international accounting standard for the extractive industries. This story cannot be conveyed by a perfunctory analysis of the positions for and against the IASC/IASB's proposals and how these might be linked to the outcome of the process. Rather, it is necessary to consider who took these positions, in addition to identifying others perhaps less visibly involved, in order to gain insight into how the accounting standard was developed. To tell this story, the international accounting standard setting process for the extractive industries was examined with a view to illuminating the political nature of accounting, and exposing the underlying institutions and arrangements of accounting.

\section{RESEARCH APPROACH: CRITICALLY EXAMINING THE PROCESS}

International accounting standards are set within an institutional context that incorporates the IASC/IASB funding arrangements and the IASC/IASB due process procedures. Within this institutional structure, IASC/IASB constituents may participate in the standard setting processes. Examining these constituents and their role is crucial to a critical investigation of international accounting standard setting process because it enables the researcher to go behind the scenes of the process to make visible the powerful coalitions and players that contribute to and influence the process. Importantly, without this deep, multi-layered analysis, these coalitions and players would otherwise remain masked by the seemingly transparent and objective international accounting standard setting arrangements. 


\section{The IASC/IASB funding arrangements}

The IASC launched its external funding program in 1990, with revenue received from three main sources: fees paid by Board members and by the International Federation of Accountants, profits made on IASC publications, and voluntary contributions made by companies and other organisations with an interest in the work of the IASC (International Accounting Standards Committee, 1999). Under these arrangements, the major international accounting firms were the IASC's largest source of funding (International Accounting Standards Committee, 1993).

This funding model was considered a threat to the legitimacy of the international accounting standards because the IASC relied on voluntary endorsement of, and compliance with, its standards from the same constituents who were funding its activities. In an attempt to overcome this problem, the Committee was restructured in 2000 and the International Accounting Standards Committee Foundation (IASCF) was formed as a not-for-profit entity. A board of trustees was appointed to the Foundation and charged with the responsibility of raising funds to support the international accounting standard setting activities (International Accounting Standards Board, 2004a). The IASC was renamed the International Accounting Standards Board (IASB) and the trustees also became responsible for appointing members to the Board and overseeing the IASB's activities (International Accounting Standards Board, 2004a).

Under the new funding arrangements, large multinational corporations, stock exchanges, national accounting standard setting bodies, central banks, government entities, international agencies, and international accounting firms became the benefactors of the IASB (Brown, 2004, International Accounting Standards Committee Foundation, 2004). The major international accounting firms continued to be the primary benefactors, with each pledging to contribute $£ 1$ million per annum to the IASB, approximately one-third of the IASB's estimated operating budget. In 2004, the IASB received contributions totalling over $£ 9$ million from 184 corporations, associations, and other institutions, including a number of the world's leading multinational corporations such as BP plc, Shell International, General Electric, Pfizer, Vodaphone, and the New York Stock Exchange (International Accounting Standards Committee Foundation, 2004).

Despite these efforts to improve the actual and perceived transparency of the external funding program, the arrangements continued to come under attack from commentators who suggest that there still existed a dependency relationship between the IASC/IASB and its benefactors, which may influence the issues considered (Brown, 2004, Mitchell, et al., 1994, Mitchell and Sikka, 1993). For example, it has been argued that critical issues, such as environmental and social accounting and accounting for small and medium sized enterprises, are marginalised in favour of those that align with the political and economic interests of supporters (Brown, 2004). Brown (2004) further noted that the IASB's current agenda items, which cover business combinations, present value, financial instruments, and extractive industries, are indeed consistent with concerns facing the large, multinational conglomerates that support the IASB. A related transparency issue in the international accounting standard setting arrangements involves the due process procedures followed by the IASC/IASB when developing a standard. 


\section{The IASC/IASB due process}

The IASC/IASB's due process procedures were designed to protect the openness, neutrality, and independence of the accounting standard setting process and enable arguments for and against proposals to be raised at several points during the development of a standard (International Accounting Standards Board, 2004a). The due process for the extractive industries accounting standard began in 1998 when the IASC added the project to its formal agenda. There is no publicly available information regarding how, by whom, or why the extractive industries project was initiated, however the international prominence, economic influence, and divergent accounting practices of the extractive industries were listed as factors contributing to the importance of the project (International Accounting Standards Committee, 2000a). Further, as will be revealed in subsequent sections, many of the IASC/IASB's financial underwriters and supporters are extractive industries enterprises. Thus, it may be argued that the admission of the project to the IASC's agenda, at least in part, was a consequence of the relationship between the IASC and its extractive industries benefactors (Brown, 2004; Mitchell and Sikka, 1993).

The IASC's extractive industries project aimed to address accounting measurement and disclosure issues for the extractive industries, and was led by a Steering Committee developed specifically for the project (International Accounting Standards Committee, 2000b). The Steering Committee was internationally representative, with members from Australia, Canada, Germany, India, Italy, South Africa, Switzerland, the United Kingdom (UK), and the United States of America (US) (International Accounting Standards Committee, 2000a, Micallef, 2001). The professional backgrounds of Committee members were also varied and included past and/or present partners of each of the Big 4 accounting firms, past and/or present mining and petroleum company executives, academics, and financial analysts.

The Steering Committee reached its first milestone in November 2000, with the publication of the Extractive Industries Issues Paper. The Issues Paper was a 412 page document consisting of 16 chapters, which raised a number of "Basic Issues" concerning matters such as reserve estimation and valuation, recognition and measurement of inventories, and financial statement disclosures. The Issues Paper was published with an invitation for interested parties to comment by 30 June 2001 on the matters raised. In addition, given the "widespread interest" in the project, the Steering Committee also sent the Issues Paper to the "senior financial officers of nearly 300 extractive industries companies worldwide" with a direct request for comment (International Accounting Standards Committee, 2000b, p.19). To guide commentators, the Issues Paper set out the Steering Committee's tentative views on some of the issues considered most significant. Respondents to the Issues Paper were required to indicate their preferences on the Basic Issues raised and thereby indicate their agreement or disagreement with the Steering Committee's tentative views.

\section{The comment letters}

Despite the Steering Committee's efforts to elicit responses, and the supposed interest in the project, 52 comment letters were received in respect of the Issues Paper. These were from respondents in countries including Australia, Canada, China, Germany, South Africa, the UK, and the US. The principal activities of the respondents were varied and included mining and petroleum companies, extractive industries lobby groups, international accounting firms, professional accounting bodies, standard setting bodies, and academics. An analysis of respondents according to location, and a categorisation as mining companies, 
mining industry lobby groups, petroleum companies, petroleum industry lobby groups, accounting firms, professional accounting and standard setting organisations, and others (academics and individuals), was most revealing. The majority of comment letters were received from Australian commentators (21 percent), followed by the UK (19 percent), South Africa (13 percent), the US (13 percent), Germany ( 8 percent), and Canada ( 4 percent). Petroleum companies and petroleum industry lobby groups were the largest respondent group (33 percent), followed by mining companies and mining industry lobby groups (29 percent), professional accounting and standard setting organisations (25 percent), the Big 4 accounting firms ( 7 percent), and others (6 percent).

In relation to the pre-production activities, respondents to the Issues Paper were asked to comment on which of the four methods of accounting for pre-production costs should be adopted by an international accounting standard for the extractive industries (full cost, successful efforts, area-of-interest, appropriation) (International Accounting Standards Committee, 2000a). In addition, respondents were to indicate whether they advocated the use of only one of these methods or whether more than one method should be permitted. The Steering Committee's tentative view was that a method consistent with the successful efforts concept should be adopted and that only this method of accounting for pre-production costs should be permitted.

There was overwhelming support for the use of the successful efforts method of accounting with 87 percent of respondents commenting on this issue indicating a preference for the successful efforts method only. In contrast, only 13 percent of respondents commenting on this issue indicated their support for having the option of both the successful efforts and full cost methods. Thus, the Steering Committee's tentative view on this issue was supported, with the majority of respondents preferring a single method of accounting for pre-production costs consistent with the successful efforts concept.

This content-based type of analysis is characteristic of most studies of accounting standard setting. It is also considered to be preliminary in this research because it is limited in three respects: First, who is making a particular argument and what is being said is masked by the aggregation of the responses. Treating submissions as votes does not take into account the identity of the respondents making the submissions, nor does it reflect the decision making processes of the IASC/IASB, which is arguably more complex than a simple tally of preferences (Walker and Robinson, 1993). Secondly, the relationships and coalitions between the respondents and other key (but perhaps less visible) players in the process remains hidden. Simply because a company does not respond directly, and therefore publicly, to the IASC/IASB on a proposed issue does not mean that they have played no part in the accounting standard setting process (Walker and Robinson, 1993). Thirdly, based on the preliminary analysis, there appears to be little conflict among respondents and the IASC. This apparent absence of conflict over the successful efforts and full cost methods is contrary to the long-standing and intense debate that has surrounded this issue. As such, it is pertinent closely to examine the responses, the respondents and other key players in the extractive industries, and the relationship between them. This type of critical analysis seeks to reveal how shared meanings may be created between the players and how this ultimately influences the development of the accounting standard. 


\section{MAKING CONNECTIONS}

Analysis of the raw demographic data obtained from the comment letters submitted in response to the Issues Paper showed that the majority of respondents agreed with the Steering Committee's proposal to mandate the use of the successful efforts method only when accounting for pre-production activities. This analysis, although relatively superficial, is useful for summarising responses and as a starting point for subsequent investigations of power/capture. To conduct these investigations, closer examination of the respondents was undertaken and revealed a number of overlapping interests between the key players. The overlaps have been categorised in terms of funding, representation, and relationships, and are summarised in Figure 1.

Figure 1. Summary of overlaps between the IASC/IASB, the Big 4, extractive industries companies, and industry lobby groups

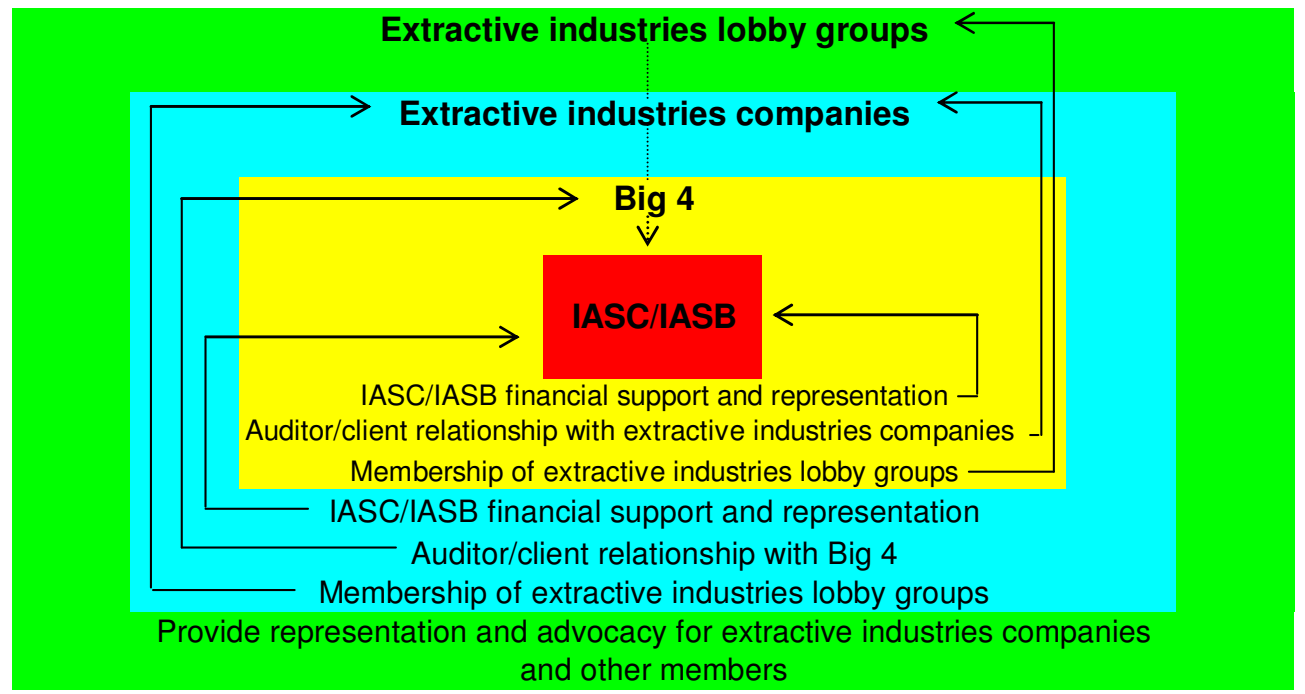

At the centre of these overlaps is the IASC/IASB. Overlaps exist between the IASC/IASB and other key players due to the funding arrangements of the IASC/IASB and key players' representation on the boards and committees of the IASC/IASB. The Big 4 accounting firms are portrayed as the first layer of overlap because of the substantial financial contribution made by these firms to the IASC/IASB and the high level of representation of the Big 4 on the boards and committees of the IASC/IASB. Following the Big 4 are extractive industries companies, which overlap with the Big 4 in terms of auditor/client relationships and with the IASC/IASB in terms of funding and representation. The third layer comprises the industry lobby groups which represent the interests of members (which includes extractive industries companies and the Big 4) when liaising with the IASC/IASB. Figure 2 provides an example of one of these overlaps. 
Figure 2. Example of overlaps between the IASC/IASB, KPMG, BHP Billiton, and the American Petroleum Institute

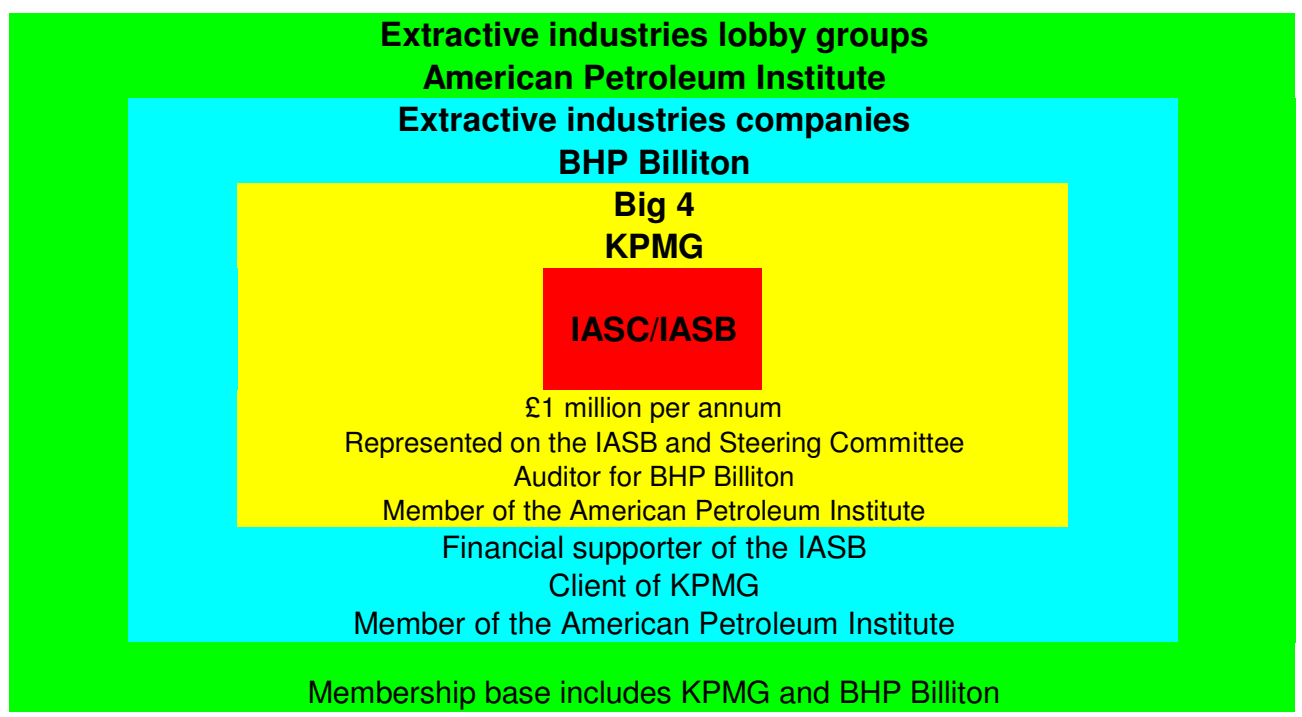

As noted, the IASC/IASB benefits substantially from the Big 4 and, as shown in Figure 2, KPMG contributes $£ 1$ million per annum in financial support. KPMG is also represented on the IASB Boards and Committees, including the Steering Committee that was responsible for the preparation of the Issues Paper. However, as well as providing financial, personnel, and technical support, Big 4 firms serve an important liaison function between the IASB and their clients. For example, at least one of the Big 4 have a focus group, comprising representatives of its extractive industries based clients, which meets monthly to discuss issues arising from IASB developments, provide training on the implementation of IASB pronouncements, and formulate responses to IASB proposals (Personal communication, 2004). Georgiou (2004) provided evidence that a considerable number of companies lobby the IASB through their external auditor, thus requiring extensive consultation between auditor and client in order to ensure that client interests are accurately represented. Ryan et al. (1999, p.177) also noted the tendency of auditors to "adopt the position of their clients" when participating in the accounting standard setting process. That these international accounting firms advocated the use of a single method of accounting consistent with the successful efforts method is not surprising given that their extractive industries client base is likely to comprise the major players in the extractive industries that already using the successful efforts method for accounting for exploration and evaluation costs.

Given the relationship between the IASC/IASB and the Big 4, and the Big 4 and their clients, an indirect relationship is established between the IASC/IASB and the major corporations, creating another layer of influence between the IASC/IASB, the Big 4, and the major corporations. This influence is heightened by the direct relationship between some of these companies, for example BHP Billiton, as shown in Figure 2, and the IASC/IASB in terms of financial support and/or representation. That is, not only does BHP Billiton have the potential to influence the IASC/IASB indirectly through its affiliation with KPMG, it also has a direct relationship with the IASC/IASB through the financial support it provides. 
As shown in Figures 1 and 2, the third layer comprises the extractive industries lobby groups that participated in the international accounting standard setting process. The American Petroleum Institute (API)'s membership list, which was used for the example, includes six of the world's top twelve companies that together earned revenues in excess of US\$1.2 trillion during 2005. The membership list of another lobby group, the Oil Industry Accounting Committee (OIAC), was more elusive than the API's, however the members that could be identified were equally impressive and also included each of the Big 4 . While each of these lobby groups' memberships included the major extractive industries players, they also represented hundreds of smaller, independent companies that together represent a formidable force against regulatory bodies such as the IASC/IASB. In their responses to the IASC in respect of the Issues Paper, both the API and the OIAC argued strongly for the retention of the full cost and successful efforts methods of accounting.

Interestingly, while some of the members of these coalitions individually responded to the Issues Paper and commented that they agreed with the IASC's proposal to eliminate the full cost method, they were also likely to be instrumental in the development of the policy positions taken by the lobby groups that represented them. For example, BHP Billiton submitted an independent comment letter in response to the Issues Paper that supported the requirement of a single method of accounting for exploration and evaluation consistent with the successful efforts method. However, the API's comment letter was vehemently opposed to the elimination of the full cost method. Another example is the position taken by the OIAC and those taken by the Big 4, which are also members of the OIAC. While PwC and Deloitte indicated their support for the IASC's proposal to require only the successful efforts method, the OIAC strongly opposed this proposal. However, the collaboration of the OIAC's members in developing the position taken by the Committee must have been substantial, given that KPMG's response to the IASC was identical to that submitted by the OIAC.

This introductory analysis of the constituents highlights the complexity and intricacy of the overlaps between key players in the international accounting standard setting process for the extractive industries. As noted, the IFRS that was eventually issued, essentially codified existing industry practice, thus perpetuating the existing flexibility in extractive industries accounting and permitting extractive industries companies to continue to use whichever method of accounting was deemed most appropriate by management to account for the exploration and evaluation activities (International Accounting Standards Board, 2004b). Therefore, the new international accounting standard for the extractive industries was in fact not new at all, and merely reinforced the existing status quo, flexibility in financial reporting. This is consistent with Mitchell and Sikka's (1993, p.29) observation that the "institutions and practices of accountancy are collusive and undemocratic" and that institutions, such as the IASC/IASB, are "dedicated to defending the status quo and sectional interests rather than wider interests".

\section{CONCLUSIONS}

The IASC/IASB's extractive industries project was commenced in 1998, with the objective of enhancing comparability and consistency of extractive industries accounting and financial reporting. Issued in December 2004, the outcome of the IASC/IASB's project, IFRS 6 Exploration for and Evaluation of Mineral Assets, is simply a codification of existing industry practice. In other words, despite all of the time, money, and other resources expended to eliminate divergent accounting practices within the extractive industries, nothing has changed. 
The purpose of this research has been to uncover the coalitions involved in the international accounting standard setting process for the extractive industries. Future research is warranted to extend the study to a wider range of constituents and explore the players more deeply. In addition, the integration of a theoretical lens such as institutional theory, particularly institutional isomorphism, and/or one which specifically theorises the power and politics involved in regulatory processes, would assist in understanding and interpreting the standard setting process, and provide insights into the development of other international financial reporting standards. While the politicisation of accounting standard setting is widely acknowledged, the revelation that economically dominant groups can, by forming formal and informal coalitions, wield such influence is a sobering one in the light of the worldwide promotion and adoption of International Financial Reporting Standards.

\section{REFERENCES}

American Petroleum Institute (2006), About us, available at http://apiec.api.org/aboutapi/index.cfm?bitmask=001010000000000000, Accessed: 2006, February 6.

Anderson, S. and Cavanagh, J. (2000), Top 200: the rise of global corporate power, available at http://www.globalpolicy.org/socecon/tncs/top200.htm, Accessed: 2006, April 14.

Bachrach, P. and Baratz, M.S. (1970), Power and Poverty: Theory and Practice, Oxford University Press, New York, USA.

Brown, A.M. (2004), "The milieu of the IASB", Journal of American Academy of Business, Vol.5, No.1-2, pp.385-390.

Cousins, J. and Sikka, P. (1993), "Accounting for change: Facilitating power and accountability", Critical Perspectives on Accounting, Vol.4, No.1, pp.53-73.

Fortune Magazine (2005), Fortune Global 500 2005, available at http://money.cnn.com/magazines/fortune/global500/, Accessed: 2006, February 13.

Georgiou, G. (2004), "Corporate lobbying on accounting standards: Methods, timing and perceived effectiveness", Abacus, Vol.40, No.2, pp.219-237.

Global Policy Forum (2006), Transnational Corporations, available at http://www.globalpolicy.org/socecon/tncs/index.htm, Accessed: 2006, April 14.

International Accounting Standards Board (2004a), About, available at http://www.iasb.org/about/general, Accessed: 2004, July 23.

International Accounting Standards Board (2004b), IASB issues Standard on the Exploration for and Evaluation of Mineral Resources, available at http://www.iasb.org/news/iasb.asp?showPageContent=no\&xml=10_249_29_09122004.htm, Accessed: 2005, November 18.

International Accounting Standards Committee (1993), IASC Insight, June, IASC, London, UK. International Accounting Standards Committee (1999), Annual Review IASC, London, UK.

International Accounting Standards Committee (2000a), Extractive Industries Issues Paper, available at http://www.iasb.org/uploaded_files/documents/16_16_iss_sum.pdf, Accessed: 2003, December 20.

International Accounting Standards Committee (2000b), IASC Insight, December, IASC, London, UK.

International Accounting Standards Committee Foundation (2004), Annual Report available at http://www.iasb.org/uploaded_files/documents/8_24_ar2004.pdf, Accessed: 2006, January 19.

Micallef, F. (2001), "A black hole?" Australian CPA, Vol.71, No.11, pp.72-73.

Mitchell, A., Puxty, T., Sikka, P. and Willmott, H. (1994), "Ethical statements as smokescreens for sectional interests: The case of the UK accountancy profession", Journal of Business Ethics, Vol.13, No.1, pp.39-51.

Mitchell, A. and Sikka, P. (1993), "Accounting for change: The institutions of accountancy", Critical Perspectives on Accounting, Vol.4, No.1, pp.29-52.

Personal communication (2004), "Focus group attendance, Deloitte Touche Tohmatsu", Sydney.

Ryan, C., Dunstan, K. and Stanley, T. (1999), "Constituent participation in the Australian public sector accounting standard-setting process: the case of ED 55", Financial Accountability \& Management, Vol.15, No.2, pp.173-200.

Van Riper, R. (1994), Setting Standards for Financial Reporting: FASB and the Struggle for Control of a Critical Process, Quorum Books, Connecticut, USA.

Walker, R.G. and Robinson, P. (1993), "A critical assessment of the literature on political activity and accounting regulation", Research in Accounting Regulation, Vol.7, pp.3-40. 
The Australasian Accounting Business \& Finance Journal, August, 2007

Cortese, Irvine, Kaidonis: Standard Setting Extractive. Vol. 1, No. 3.

World Bank (2005), World Development Indicators 2005 available at http://web.worldbank.org/WBSITE/EXTERNAL/DATASTATISTICS/0,,contentMDK:2052371 0 hlPK:1365919 menuPK:64133159 pagePK:64133150 piPK:64133175 theSitePK:239419,0 0.html, Accessed: 2006, April 14. 